\title{
Agrarian Reform in Indonesia: Analyze Concepts and Their Implementation from a Governance Perspective
}

\author{
Hariadi Kartodihardjo ${ }^{1 *}$, Eko Cahyono ${ }^{2}$
}

${ }^{1}$ Department of Forest Management, Faculty of Forestry and Environment, IPB University, Academic Ring Road, Campus IPB Dramaga, Bogor, Indonesia 16680

${ }^{2}$ Sajogyo Institute, Jl. Malabar No. 22 Bogor, Indonesia 16151 and Departement of Communication Science and Community Development, Faculty of Human Ecology, IPB University, Academic Ring Road, Campus IPB Dramaga, Bogor, Indonesia 16680

Received February 16, 2021/Accepted October 5, 2021

\begin{abstract}
Analysis of the relationship between inequality, agrarian reform, and corruption as well as public administration reform has not been discussed, both in terms of the formation and implementation of agrarian reform in Indonesia. This article aims to explore the concept and implementation of agrarian reform, as well as the influence of governance conditions in the management of natural resources in the implementation of agrarian reform. With the characteristics of agrarian issues in Indonesia, land administration and those related to the implementation of redistribution of benefits from the use of natural resources need to be strengthened with appropriate concepts or theories, including public information disclosure as a fulfillment of substantive and deliberative implementation of democracy. In addition, by referring to experiences in other countries, agrarian reform needs to be carried out by reducing the level of clientelism and implemented through a number of corruption prevention and prosecution programs, especially in the fields of land and other natural resources.
\end{abstract}

Keywords: agrarian reform, corruption, administrative reform, deliberative, clientelism

*Correspondence author: hariadi@apps.ipb.ac.id

\section{Introduction}

The definition of "agrarian" in Indonesia is often narrowed down to "agricultural land", whereas what is covered by agrarian includes natural resources as a whole (Wiradi, 2005). In Law Number 5/1960 concerning Agrarian Principles, Article 1 explains that the definition of agrarian, apart from the surface of the earth, is also the body of the earth beneath it, is also under water, and in the sense that water includes sea. Agrarian reform is defined as "restructuring or renewing the structure of ownership, control and use of land/territory, in the interest of small farmers, landless farmers and landless farm workers" (Wiradi, 2005). In line with this, Lipton (2009) defines land reform as legislation intended and likely to directly redistribute ownership of, claims on, or rights to farmland, and thus to benefit the poor by raising their absolute and relative status, power, and income. compared with likely situations without the legislation.

The attention to agrarian reform has also been very long, with various developments. The experience of "land reform" which is only in the form of "redistribution" or redistribution of land has not been successful, because farm workers who acquire land, many are unable to cultivate their land themselves due to lack of capital, lack of skills and so on. Finally the farmer sold the land. Based on this long experience, it was realized that "land reform" needed to be accompanied by supporting programs such as credit, provision of production facilities, education and others, and was later called "agrarian reform" (agrarian reform). In this case, the term "reforma" needs to be distinguished from the term "management", because the term "reforma" emphasizes more on the form of operations, "ad hoc" and fast (Wiradi, $2005)^{1}$. Thus, ideally agrarian reform is not a program or merely a "normal" development policy, but it is a "foundation" or the supporting base of national development policies.

Meanwhile, land governance is basically meant to understand the power and political economy of land. This

\footnotetext{
According to Sediono M. P. Tjondronegoro, "The implementation of agrarian reform, ... (preferably) is done centrally, integrally and simultaneously (sic!). This simultaneous element actually contains a positive element, because the implementation of agrarian reform for any land ruling class is also unpleasant and a sacrifice. Therefore, agrarian reform should be carried out simultaneously and in the shortest possible period. The better the planning, implementing and supervisory apparatus (including the courts) is "clean," the greater the authority of the authorities, and the wider community is likely to obey".
} 
involves the rules, processes and structures by which decisions regarding land use and tenure are made, how decisions are implemented and enforced, and how competing interests in land are managed (Palmer et al., 2009). Thus, effective and enforceable land governance can provide the necessary framework for development and critical defense to fight against various forms of corruption (Arial et al., 2011).

Land corruption is often the cause or descent of the failure of governance of a country as a whole. The findings of Arial et al. (2011) show that there is a very strong correlation between the level of corruption in the land sector and the corruption of the public sector as a whole in a country. These results suggest that countries facing widespread public sector corruption also suffer from corruption in the land sector. These findings have broad and important implications for ensuring the integrity and effectiveness of initiatives related to natural resource management, including the implementation of agrarian reform.

This paper aims to explore the concept and implementation of agrarian reform in Indonesia as well as the influence of governance conditions in natural resource management in the implementation of agrarian reform.

\section{Inequality and Governance Problems in Indonesia}

In Indonesia, about $56 \%$ of national assets are controlled by only $0.2 \%$ of the Indonesian population (Winoto, 2010). The national assets are between $62 \%$ and $87 \%$ in the form of land. The data from TNP2K (2019) $)^{2}$ states that $1 \%$ of Indonesia's population controls $50 \%$ of national assets. Meanwhile, the World Bank (2015) states that 1\% of Indonesia's population controls $50.3 \%$ of the country's total wealth $^{3}$. Another figure from INFID and OXAM (2017) states that the 10 richest people control their assets, equivalent to 100 million poor people in Indonesia.

In the case of the plantation sector, 25 large oil palm plantation companies control 5.8 million ha of the 16 million ha in Indonesia. The wealth of 29 conglomerates related to the palm oil business in Indonesia is estimated to be equivalent to $67 \%$ of the 2017 State Budget (APBN). In that period, the government budgeted an APBN of IDR2,080 trillion consisting of central government spending, transfers to regions and funds village. Meanwhile, the total assets of the 29 tycoons were recorded at USD88 billion, equivalent to IDR1,241 trillion (referring to the exchange rate of IDR14,112 USD $\left.{ }^{-1}\right)(\mathrm{TuK}, 2018)^{5}$. Referring to Sawit Watch (2019) data from an area of oil palm companies in 2019, covering 22.8 million ha, the control is divided into three groups, namely by the government (PTPN) 10\%, private/cooperative $55 \%$ (around 30 companies) and by farmers (small holder) 35\%. From small holder farmers (by the people) covering an area of approximately 7.8 million ha, if the average control is 24 ha, it will be sufficient only for 3 million families. Thus, there is a wide disparity between the control of oil palm by private companies, the state and the people.

Previously, the development of natural resource use was concentrated in the western region of Indonesia, but now it has utilized lands in eastern Indonesia, especially Papua and West Papua ${ }^{6}$. Data from the Corruption Eradication Commission (KPK) shows that illegal and corrupt permits and concessions of natural resources occurred in the majority of regions, increased after the decentralization policy was implemented and generally occurred through regional head elections ${ }^{7}$, although some cases still involved national political nets. The KPK survey (2018) shows that $82.3 \%$ of the candidates for regional heads interviewed admit that there are donors in the election funding. This has led to the issuance of plantation, forestry and mining permits in the regions and has triggered increased damage and a more severe socio-ecological crisis (Kenny \& Warburton, 2021). The momentum of election politics is like being the regular season for 5 years of "permit sales" for the use of natural resources. Along with that, the ecological damage is also increasing ${ }^{8}$.

Based on the facts above, the re-entry of agrarian issues in the realm of national policy is a necessity. This is because, however, the land reform policy is an operation which requires a legitimate state power to take measures to limit the privileges of land rulers whose land is to be controlled and utilized (Christodolou, 1990). Agrarian reform and social forestry policies have been included in the 20142019 RPJMN and are resumed in the 20202024 RPJMN. A total of 12.7 million ha of forest area are used as social forestry and 9 million ha as land objects for agrarian reform. With this program, it is hoped that inequality in the use of forest areas, for example, which in 2014 was used for the private sector covering an area of 32.7 million ha and utilized by the community covering an area of 449,114 ha can be redistributed more to make it more equitable. In addition, there is also a program to settle land rights in forest areas. This program in early 2020 has a target of 4.97 million ha.

In this policy, the land scheme for the object of agrarian reform is implemented through two models, namely the restructuring of the land sector through the legalization of assets covering an area of 4.5 million ha and the provision of land access through land redistribution of 4.5 million ha. As of October 2018, the achievements of the agrarian reform policy, in terms of asset legalization or land privatization, amounted to 6.2 million land certificates. PS achievements until the period of September 2018, covering an area of

\footnotetext{
${ }^{2}$ https://nasional.kompas.com/read/2019/10/09/17023551/tnp2k-satu-persen-orang-indonesia-kuasai-50-persen-aset-nasional

3 https://www.worldbank.org/in/news/feature/2015/12/08/indonesia-rising-divide

${ }^{4}$ https://kumparan.com/manik-sukoco/lebarnya-ketimpangan-ekonomi-indonesia

5 https://indonesiainside.id/ekonomi/2019/01/31/25-taipan-kuasai-separuh-lahan-sawit-di-indonesia

The Indonesia Monitoring CSO Coalition, which delivered a Press conference (10 February 2021), on "To the East: The Direction of Indonesian Deforestation", the main finding was that although national deforestation decreased, the rate of deforestation remained high in forest-rich provinces in Indonesia. In fact, there is an increasing trend in Eastern Indonesia. In Tanah Papua, one of the triggers is the policy of releasing forest areas for oil palm plantations, which incidentally is only for corporations.

See further, https:/www.kpk.go.id/id/berita/berita-kpk/1923-ketua-kpk-pastian-penyelidiki-korupsi-kepala-daerah-tetap-jalan

See further, "Tinjauan Lingkungan Hidup" (Environmental Outlook) Walhi, 2018 and 2019.
} 
$1,849,146.07$ ha or $1.47 \%$ of the designated forest area in the form of community forests, village forests, community plantation forests and partnerships. Meanwhile, the achievement of settlement of land rights in forest areas by February 2020 is 2.46 million ha or $59 \%$ of the target (KLHK, 2020).

In practice, these various programs have several problems and challenges, both substantive, administrative, and political. In the implementation of the agrarian reform policy, the objective of asset legalization or land privatization is too dominant, there is minimal redistribution of land and is still far from the spirit of "restructuring" of various agrarian inequalities (Cahyono \& Galudra, 2019). Meanwhile, land objects for agrarian reform are still dominant in the forestry sector, while the plantation, mining, coastal and marine sectors, small islands which are also experiencing crises, conflicts and agrarian inequality have not been touched by current national agrarian change policies ${ }^{9}$. Meanwhile, the fact is that indigenous peoples who had de facto existed before Indonesia's independence were also very slow to gain recognition by the state ${ }^{10}$.

So far, the designation of customary forest is still very limited, namely $35,202.34$ ha, while the forest area which is still at the designated stage for customary forest is 914,927.13 ha (KLHK, 2020). On April 29, 2019, the Minister of Environment and Forestry issued Decree of the Minister of Environment and Forestry Number 312/2019 concerning Map of Indigenous Forests and Indigenous Areas of Indigenous Forests Phase I covering an area of 472,981 ha consisting of an indicative map of customary forest 453,831 ha consisting of state forest covering 384,896 ha and from other use areas covering an area of 68,935 ha, as well as the stipulation of a customary forest decree covering an area of 19,150 ha. The area of the indicative map is spread across five regions, namely $64,851.17$ ha (Sumatera), 14,818.49 ha (Java, Bali, Nusa Tenggara), 54,978.98 ha (Kalimantan), 261,323.01 ha (Sulawesi), and 77,009.57 ha (Maluku and Papua).

In early August 2020, the Ministry of Environment and Forestry (KLHK) stipulated an additional 101,293 ha of indicative customary forest in the indigenous forest map and the indicative area of customary forest phase II with the additional amounting to 555,124 ha. Meanwhile, based on data from the Ministry of Environment and Forestry, there are proposals for customary forest covering an area of 9.3 million ha from various parties and it has been analyzed with a map of forest areas, with an area of 6,551,305 ha located in forest areas. Of that area, 2,890,492 ha do not have legal products and 3,660,813 ha are legal products. However, the legal products that recognize indigenous peoples are still different and are divided into four clusters. An area of 6,495 ha has a regional regulation recognizing indigenous peoples, 185,622 ha has a regulatory regulation and a recognition decree, 226,896 ha has a decree on the recognition of indigenous peoples, 3,067,819 ha has a regulation, and 274,771 ha has other legal products.

During the recognition period of the customary forest, there was an amendment to the Minister of Forestry Regulation Number 32/2015 concerning Private Forests replaced by the Regulation of the Minister of Environment and Forestry Number 21/2019 concerning Customary Forests and Private Forests. However, this new ministerial regulation in Article 5 still states that requests for designation of customary forests to the Minister must have legal products for recognition of customary communities in the form of regional regulations for inside state forest areas and regional regulations or regional head decrees for customary forests outside state forest areas.

In practice, this provision will still be an obstacle, because the enactment of these regional regulations takes a long time and is expensive. According to Yando Zakaria ${ }^{11}$, if the government is serious about this commitment, President Joko Widodo needs to revoke Article 67 paragraph 2 of Law Number 41/1999 on Forestry, which is the legal basis for affirming indigenous peoples that there must be a regional regulation. Muhammad Arman, Director of Policy Advocacy, Law and Human Rights, Alliance of Indigenous Peoples of the Archipelago (AMAN) also said similarly. "The Minister of Environment and Forestry Regulation Number 21/2019 actually complicates the process. The approach is still very bureaucratic". He questioned, regulations that were considered breakthroughs were unlikely to be instruments of conflict resolution.

The conditions for the implementation of these programs are also hampered by the prioritization of exploiting natural resources that are extractive in nature, which can occupy the same space, both for agrarian reform, social forestry, and the living locations of indigenous peoples. Dim or even the death of government functions in the working areas until the last decade is still caused by corruption in permits. Kenny and Warburton's (2021) research entitled "Paying Bribe in Indonesia: A survey of business corruption", states that companies interact with various levels of government and regional executives which open up new opportunities for corrupt exchanges between the private sector, district level bureaucrats and officials. local security. This fact, according to this study, is very detrimental to the natural resource sector. Collusion between companies and state officials has led to an explosion in the number of mining and palm oil permits, accelerating the rate of deforestation and land degradation and encouraging new and sometimes violent conflicts in resource-rich areas.

In the opinion of 672 business representative respondents interviewed by Kenny and Warburton (2021) between July 2019 and February 2020, 33.2\% claimed to have been asked for informal fees and $30.6 \%$ stated that they had paid the fee.

\footnotetext{
${ }^{9}$ See https://www.cnnindonesia.com/nasional/20200106132321-20-462771/konflik-lahan-era-jokowi-2-kali-lipat-dari-2-periode-sby; see also https://bisnis.tempo.co/read/1029128/kiara-reforma-agraria-belum-sentuh-pulau-pulau-kecil

${ }^{10}$ National Human Rights Commission (KOMNAS HAM) and CSO, National Inquiry Report on conflict resolution of Indigenous Peoples in Forest Areas, in 2015. See: https://terbitan.sajogyo-institute.org/category/buku/inkuiri-nasional/, see also https://kompas.id/baca/nusantara/2019/01/08/pengakuan-hutan-adat-sangat-lambat/

${ }^{11}$ Yando Zakaria, researcher at the Ethnography Center for Indigenous Communities in Yogyakarta, Member of the expert team at the Presidential Secretariat Office (KSP).
} 
Companies that strongly believe that illegal fees are also paid by businesses in their sector are $35.7 \%$. The companies are grouped into extraction, construction, agriculture, manufacturing, trading, logistics and finance companies.

The highest proportions of companies that reported extortion, paid bribes and believed that the practice was common in their sector, namely in construction companies, respectively $49.5 \%, 44.2 \%$, and $51.6 \%$. Followed by extractive companies, amounting to $47.9 \%, 42.7 \%$, and $53.1 \%$. The lowest proportions are in the financial sector, amounting to $17.0 \%, 16.0 \%$, and $22.3 \%$.

The potential for licensing corruption was strengthened by the results of a study by Baker (2020) which stated that a regent who had been proven to have committed forestry corruption was actually accommodated by 201 network nodes. This knot is controlled by individuals from the pulp industry (82), the District Forestry Service (47), the regent's trust network (17), the non-pulp private sector (14), the Provincial Forestry Service (9) and the Government (8). Here it is also necessary to note that although the number of government nodes is the smallest, it has the greatest role in moving the network, because it has monopoly control over the main resource. Here too, it can be shown that bureaucratic work is part of practical politics which is always under pressure from certain interests. This situation is also the reason why corruption prevention efforts can be said to be unsuccessful if they are not accompanied by actions.

Poor governance is also one of the causes of conflicts based on land or natural resources in a broad sense. The end note for the 2020 Agrarian Reform Consortium (KPA, 2020) states that the number of agrarian conflicts in the plantation sector increased by $28 \%$ and forestry increased by $100 \%$ from the previous year. Overall, the affected people reached 135,332 families. There were 160 direct victims, 139 of whom were criminalized, 19 were persecuted, 11 died. The majority of cases of violence were committed by state officials such as the police (46), the army (22), civil service police units (9) and company hired thugs security officers (20). In line with this, the National Human Rights Commission (KOMNAS HAM) noted that throughout 2018, 196 agrarian cases had received complaints in Indonesia. Meanwhile, for the JanuaryApril 2019 period, 52 cases were reported to KOMNAS HAM. The complaint covers six sectors, namely plantation, infrastructure, State Property (BMN), mining, environment, and forestry. Meanwhile, the perpetrators are the central/local government, state-owned enterprises (BUMN), corporations, and the $a r m y^{12}$.

\section{Discussion}

The implementation of agrarian reform in Indonesia is challenged by the tendency to privatize land, while there are still assumptions and facts on the ground that land privatization is not appropriate. In addition, it also faces challenges with governance problems as previously described. For this reason, we try to explore these two things through related concepts that have been running in various countries, in order to obtain options to solve these two problems.
Overview of replacement theory and conservative theory Several land reform theories (Table 1) can be used as a way of understanding the perspectives behind land reform. It can be used to examine the drawbacks or strengths of the approaches adopted by development practitioners and land policy makers. In the study of Hull et al. (2019), the typology of theory was tested with three cases of land reform in subSaharan Africa. It was found that the theory underlying land reform in the region was not in harmony with the life experiences of prospective land reform recipients and customary rights holders in the region.

Hull et al. (2019) further mentions that there is a wide debate surrounding these theories. First, replacement theorists support the substitution of customary land rights, that is, living and unmodified customary law, with legal property rights, to ensure tenure security. Therefore, certification separates land held by individuals or groups from its larger community.

Second, conservative theorists argue that an unmodified and viable customary tenure system provides adequate tenure guarantees and that land titling reduces tenure security. Adherents of this theory advocate preserving most of the indigenous cultures. If the influence of traditional leaders is strong, such as in South Africa or in Papua, such an approach can be discouraged as anti-democratic.

Between the replacement theory and the conservative theory there is a third school of thought, namely the adaptation theory (Royston, 2013, in Hull et al., 2019). These experts advocate for a gradual change to land tenure systems, or the adoption of a hybrid tenure system to accommodate local needs and changes. This approach, which Hull et al.(2019) once called the "renovation" of customary ownership, recognizes the value of living systems of customary tenure while suggesting that their "defects" can be overcome in creative ways to accomplish them, rather than more radical changes.

Replacement theorists consider surviving customary land tenure to be an obstacle to land market development and economic modernization, and propose replacing it with a system of tenure that seems more appropriate, namely private property. For replacement theorists, land titling and registration are seen as ways of solving land administration problems. This is thought to promote successful land use, increase opportunities for credit, and promote market development to increase land value.

Arko-Adjei (2011) states the logic behind the replacement theory. First, with group rights under customary tenure systems, individual tenure in it is not guaranteed. Second, because customary rights are difficult to revoke, they discourage investment and thus hinder development. Third, the common ownership associated with adat systems is outdated and is likely to disappear in the future as tenure progresses towards individualization.

Several other experts have strongly criticized the introduction of land rights and land registration in Africa, especially in sub-Saharan Africa (Platteau (1996), in Hull et al., 2019). The failure of market-oriented tenure reforms is used as evidence of increasing marginalization of the poor 
Table 1 Summary of land reform theories

\begin{tabular}{|c|c|}
\hline Theory & Possible indicators \\
\hline \multirow[t]{3}{*}{ Conservative } & Preservation of costumary tenure \\
\hline & Broadly African view of land \\
\hline & Traditional leaders prominent in land administration \\
\hline \multirow[t]{3}{*}{ Democratic adaptation } & Respecting and clarifying existing, legitimate land rights \\
\hline & Improving gender equity, accountability, and democracy \\
\hline & Building on existing customary practices \\
\hline \multirow[t]{2}{*}{ Hybrid adaptation } & Combination of statutory and customary arrangements \\
\hline & Participatory approach: communities decide which rights are recorded \\
\hline \multirow[t]{4}{*}{ Incremental adaptation } & Titles are a long-term objective \\
\hline & Extra-legal, off-register practices recognised as legitimate \\
\hline & Spontaneous titling according to need \\
\hline & Titles are the desired end state \\
\hline \multirow[t]{2}{*}{ Incremental replacement } & Customary tenure provides sufficient tenure security \\
\hline & Legal recognition of customary tenure and adjudication practices \\
\hline \multirow[t]{2}{*}{ Evolutionary replacement } & Land rights spontaneously evolve towards individualisation \\
\hline & Titles are required for tenure security \\
\hline \multirow[t]{3}{*}{ Collective replacement } & Nationalisation of all land/collective farming villages \\
\hline & Equitable distribution of resources and services \\
\hline & $\begin{array}{l}\text { Democratisation of traditional leadership Improved productivity and self- } \\
\text { reliance }\end{array}$ \\
\hline \multirow[t]{3}{*}{ Systematic titling } & Titles are required for tenure security \\
\hline & Titling leads to economic development \\
\hline & Customary tenure must be replaced \\
\hline
\end{tabular}

Sources: Chitonge et al. (2017), in Hull et al. (2019).

and their exploitation by the elite. Meanwhile, Bruce (1993) suggests that more attention should be paid to solutions by paying attention to community opinions and needs as a solution to tenure insecurity and the evolution of changes to the customary land tenure system facilitated by the state.

Meanwhile, conservative theory sees living customary ownership as providing adequate tenure security because land acts as a social, political and economic bond between kinship groups (Nkwae, 2006). This point of view stems from a multi-functional, multi-generational understanding of land from an African perspective, where land forms the foundation of socio-economic, religious and political systems. Land titling programs may fail in such a context because certification undermines the social structure of rural communities, so that de jure tenure security can erode preexisting and socially entrenched de facto tenure security.

In this sense, the role of traditional leaders is very important in conservative theory, because they are responsible for land allocation and administration. However, it was from the view of the traditional pre-colonial leaders that they could become autocratic rulers who paid little attention to the wishes of their people. This conservative theory view, according to Delius (2008), in Hull et al. (2019), is considered biased, and that the alternative perspective emphasizes the implementation of the consultative dimension and the democratic process.

Furthermore, Bruce (1993) warns that the conservative theory view may only apply in situations of subsistence farming and land abundance. Therefore, it is advisable to avoid romantic statements, as such systems can experience problems of gender discrimination, or abuse of power by heads, traditional councils, or community leaders. For this reason, democratic adaptation theory can be an alternative.

Inequality, agrarian reform and corruption Jong-sung's (2014) study found evidence on two main causal mechanisms from inequality to corruption, such as state capture and clientelism. High inequality can increase the pressure on redistribution efforts, in which the rich then have a stronger incentive to influence the policy-making and implementation process. In conditions of high inequality, economic and political elites also have an incentive to develop clientelism and the poor are vulnerable to clientelism because it hinders the implementation of their collective action.

In Korea and Taiwan, land reform as an effort to minimize inequality can reduce the influence of the dominant class on state autonomy due to the loss of the land elite. Both Korea and Taiwan were able to build meritocratic and autonomous bureaucracies, which were largely free from influence and penetration by these dominant interests. Political clinicalism and vote-buying practices exist in Korea and Taiwan as well, but programmatic politics evolves over time and clientelism gradually diminishes in significance (Jong-sung, 2014).

Conversely, the failure of land reform in the Philippines helps oligarchs to maintain and expand their economic power by diversifying into trade, manufacturing and finance (Wurfel, 1988 in Jong-sung, 2014). The land oligarchy accumulates not only economic wealth, but also political power because the patron-client relationship between landlords and tenants can easily be used for vote 
mobilization. The study also found that Philippine legislators are usually members of wealthy landlord families.

The existence of this causal mechanism suggests that the effect of democracy on corruption can vary depending on the level of inequality. Democratic control of corruption may not function well under high levels of inequality, because clientelism prevents voters from punishing corrupt politicians and because the policy process is influenced by elites. The character of democracy which is still entangled in patronage practices and the political octopus of clientism also occurs in Indonesia (Aspinal \& Berencshot, 2019).

Administrative reform politics Studies in twenty-five countries show that the results of agrarian reform programs are strongly influenced by the administrative arrangements for their implementation (Montgomery, 1972). The study suggests that arrangements to shift administrative functions to local non-career officials yield far better results for farmer welfare than arrangements using professional administrators, whether in centralized or decentralized bureaucratic systems. These programs have more of an impact on farmers' incomes than agrarian reform programs that provide technical assistance and credit provision.

Meanwhile, to carry out administrative reform, a bureaucratic political framework is needed (Bowornwathana \& Poocharoen, 2010). This is due to the occurrence of power plays among actors in the administration of administrative reform. For the field of public administration, all forms of public sector reform, whether it be structural reforms, managerial reforms, or behavioral and cultural reforms, it is important to pay attention to the struggle for power among actors. For that reason, politics is administration and administration is always politics.

For natural resource management, it is known as the conservation bureaucracy (Sahide, et al. 2019). Within the conservation bureaucracy there tends to be a strict interpretation of formal rules to prohibit community access and to imagine themselves as the last line of defense for forest protection. Therefore, the face of the conservation bureaucracy is often seen as forest guardian, refusal to enter and control forest boundaries. In some countries, this imagined role is measured by their ability to maintain forest quantity (not quality). Therefore, the conservation bureaucracy has traditionally defined their formal role as an agency that works to maintain biodiversity resources. Meanwhile, informally they also function as another bureaucracy, seeking to continue to expand their role by pursuing the goal of increasing the number of staff and increasing access to a portion of the budget as a whole (Fatem et al., 2018 in Sahide et al., 2019).

Implementation of agrarian reform in Indonesia Based on various concepts and experiences in other countries regarding the implementation of agrarian reform that have been described previously, the following describes the experience of the implementation of agrarian reform in Indonesia.

Coordination and administrative issues The National Agrarian Reform Program launched by the government in the era of President Susilo Bambang Yudhoyono tries to provide a holistic approach, not only looking at agrarian reform in the form of asset reform, but also touching on the access reform aspect. Basically, the program is at an ideal level, namely combining assets and access reform. However, there are several failures and weaknesses in implementation, especially regarding the implementation of access reform which requires cross-sectoral coordination (Widodo, 2017). Access reform in these other fields mainly covers capital, technical skills, facilities and infrastructure, and marketing.

In addition, according to Shohibuddin (2013), this failure was also caused by friction and fragmentation of views in addressing the agrarian reform agenda within the government bureaucracy itself. There is even friction and fragmentation among agrarian activists. For those who support it, the agrarian reform program becomes a political opportunity that must be utilized optimally. Meanwhile, those who oppose it see that the agrarian reform program only makes agrarian reform matters a technical matter for land administration and does not put it in an effort to overhaul the existing inequality of agrarian structures and avoid lands where agrarian conflicts occur.

However, what cannot be denied is that there are administrative problems that need reform, including in response to various matters, both regarding the selection and application of theories or concepts used as well as controlling corruption, all of which are aimed at reducing inequality and improving welfare for indigenous peoples and local communities other.

Inequality, licensing corruption and market led agrarian reform Indigenous and other local communities in Indonesia - especially those where they live in areas rich in natural resources - have been under pressure for a long time, as a result of not being recognized for their legal rights including being denied access to economic development for decades, even before Indonesia's independence. Thus, the issue of rights to natural resources and the existence of society becomes the most fundamental substantial issue, before discussing other problems it faces. If we also pay attention to issues of licensing management and corruption in the use of natural resources (KPK, 2018), which go hand in hand with the slow implementation of agrarian reform due to various administrative obstacles, of course the community problem becomes very complex. This is because the claims of land rights, which are generally carried out by large enterprises, directly threaten the existence of the community.

Recent developments in national politics have focused even more on facilitating the licensing process for large enterprises to utilize natural resources, rather than on explicitly protecting and developing the rights of indigenous and local communities. The birth of the Job Creation Law Number 20/2020 on November 2, 2020 and its various draft regulations aimed at facilitating the exploitation of natural resources with a contra reform character, and at the same time there has been no serious effort to resolve the issue of rights to natural resources for ordinary people. What happens is that there is an increasing clash of basic objectives of agrarian reform, which has the mandate to reduce agrarian structural inequality, resolve agrarian conflicts, save the sustainability of natural resources and the people's welfare. The Job Creation Law, which is more oriented to ease of investment 
and ease of licensing in all agrarian and natural resource sectors also shows that the orientation of agrarian reform policies is closer to the type of market led agrarian reform (Lahiff et al, 2007).

Synthesis of land reform problems in Indonesia Thus, the problems in implementing agrarian reform as an implemented instrument come from at least five sides. First, the way of thinking about the implementation of agrarian reform is still not in line with the real conditions on the ground, especially when it is related to implementation options. The collision between the conservative theory and the substitution theory has not been formulated how the solution will be, if different socio-cultural conditions are faced. Its basic character is more inclined towards the agrarian reform led market model. Second, the policy of implementing agrarian reform clashes substantially with the regulation and administrative process of determining indigenous and local communities and other social groups who are the "subjects" of agrarian reform policies that tend not to have easy access to the legality of their rights, take a long time and require political endeavors that are beyond the reach of society itself.

Third, bad governance, which has directly led to increased deforestation and various socio-ecological crises as well as the development of extractive licensing, has significantly displaced the existence of indigenous and rural communities both inside and outside forest areas. Fourth, the access of indigenous peoples to economic development from natural resource management is still low. Fifth, administrative problems and the lack of state institutions, both central and regional, to be able to carry out programs and activities that are in line with the problems mentioned above. The complexity of the problem should be used as material in determining policies for implementing agrarian reform in a more comprehensive and consistent manner.

\section{Conclusion}

The three main points outlined in the discussion above, namely regarding theoretical analysis, the relationship between inequality, agrarian reform and corruption as well as political administrative reform in general have not been discussed in terms of both the establishment and implementation of agrarian reform in Indonesia. Considering that everything described in Indonesia is a fact that underlies the implementation of agrarian reform, then land administration and those related to the implementation of redistribution of benefits from the use of natural resources need to be linked to efforts to strengthen the concepts or theories used, public information disclosure, as the fulfillment of the implementation of democracy substantive and deliberative, so that various approaches are taken in line with efforts to open up political interests and in line with the socio-cultural conditions of the people who are the main beneficiaries. In addition, by referring to experiences in other countries, agrarian reform, which can be used to reduce levels of clientelism, needs to be encouraged to implement it through a number of programs to prevent and prosecute corruption in land and natural resource corruption in a broad sense.

\section{References}

Arial, A., Fagan, C., Zimmermann, W., \& Hardoon, D. (2011). Corruption in the land sector (Transparency International Working Paper No 4). Transparency International. http://www.fao.org/3/am943e/ am943e00.pdf

Aspinal, E., \& Berenschot, W. (2019). Democracy for sale: Elections, clientelism, and the state in Indonesia. Ithaca, London: Cornell University Press.

Arko-Adjei, A. (2011). Adapting land administration to the institutional framework of customary tenure: The case of peri-urban Ghana (dissertation). Delft: Delft University of Technology.

Bowornwathana, B., \& Poocharoen, O. O. (2010). Bureaucratic politics and administrative reform: Why politics matters. Public Organ. Rev. 10(4), 303-321.

Bruce, J. (1993). Do indigenous tenure systems constrain agricultural development? In T. Basset, \& D. Crummey (Eds.), Land in African agrarian systems (pp. 35-56). Madison: The University of Wisconsin Press.

Baker, J. (2020). Jaringan korupsi di sektor kehutanan Indonesia: Politik dan pulp di Pelalawan Riau. Jakarta: CMI Michelsen Institut. Kerjasama KPK dan GIZ.

Cahyono, E., \& Galudra, G. (2019). Kebijakan reforma agraria dan perhutanan sosial di Indonesia: Refleksi dan kontekstualisasi kebijakan pembangunan nasional [Policy Brief]. Bangkok: The Center for People and Forest (RECOFTC).

Chitonge, H., Mfune, O., Umar, B. B., Kajoba, G. M., Banda, D., \& Ntsebeza, L. (2017). Silent privatisation of customary land in Zambia: Opportunities for a few, challenges for many. Social Dynamics, 43(1), 82-102. https://doi.org/10.1080/02533952.2017.1356049

Delius, P. (2008). Contested terrain: Land rights and chiefly power in historical perspective. In A. Claassens, \& B. Cousins (Eds.), Land, power \& custom: Controversies generated by South Africa's communal land rights act (pp. 211-237). Cape Town: UCT Press.

Fatem, S. M., Awang, S. A., Pudyatmoko, S., Sahide, M. A., Pratama, A. A., \& Maryudi, A. (2018). Camouflaging economic development agendas with forest conservation narratives: A strategy of lower governments for gaining authority in the re-centralising Indonesia. Land Use Policy, 78, 699-710. https://doi.org/10.1016/ j.landusepol.2018.07.018

Hull, S., Babalola, K., \& Whittal, J. (2019). Theories of land reform and their impact on land reform success in Southern Africa. Land, 8(11), 172. https://doi.org/ 10.3390/land 8110172

Jong-sung, Y. (2014). Land reform, inequality, and corruption: A comparative historical study of Korea, 
Taiwan, and the Philippines. The Korean Journal of International Studies, 12(1), 191-224.

Kenny, P., \& Warburton, E. (2021). Paying bribe in Indonesia: A survey of business corruption [Research Brief]. New Mandala: Australian National University. Retrieved from https://www.newmandala.org/wpcontent/uploads/2021/01/Paying-bribes-in-Indonesia formatted.pdf

[KLHK] Kementerian Lingkungan Hidup dan Kehutanan. (2020). Pengarahan Menteri Lingkungan Hidup dan Kehutanan pada rapat kerja nasional KLHK. Jakarta: Kementerian Lingkungan Hidup dan Kehutanan.

[KPA] Konsorsium Pembaruan Agraria. (2020). Catatan akhir Tahun 2020. Edisi Peluncuran I: Laporan konflik agraria dan masa pandemi dan krisis ekonomi. Jakarta: Konsorsium Pembaruan Agraria.

[KPK] Komisi Pemberantasan Korupsi. (2018). Sintesis: Evaluasi gerakan nasional penyelamatan sumberdaya alam. Jakarta: KPK.

Lahiff, E., Borras, Jr. S. M., \& Kay, C. (2007). Market-led agrarian reform: Policies, performance and prospects. Third World Quarterly, 28(8), 1417-1436. https://doi.org/10.1080/01436590701637318

Lipton, M. (2009). Land reform in developing countries. Property rights and property wrong. London: Routledge.

Montgomery, J. D. (1972). Allocation of authority in land reform programs: A comparative study of administrative processes and outputs. Administrative Science Quarterly, $17(1), 62-75$.

Nkwae, B. (2006). Conceptual framework for modelling and analysing periurban land problems in Southern Africa (dissertation). Fredericton: University of New Brunswick.

Palmer, D, Fricska, S., \& Wehrmann, B. (2009). Towards improved land governance (Land Tenure Working Paper 11). FAO. http://www.fao.org/3/ak999e/ak999e.pdf
Platteau, J. (1996). The evolutionary theory of land rights as applied to Sub-Saharan Africa: A critical assessment. Development and Change, 27(1), 29-86. https://doi.org/ 10.1111/j.1467-7660.1996.tb00578.x

Royston, L. (2013). In the meantime... Moving towards secure tenure by recognising local practice. In M. Napier, S. Berrisford, C. W. Kihato, R. McGaffin, \& L. Royston (Eds.), Trading places: Accessing land in African cities (pp. 47-72). African Minds: Somerset West.

Sawit Watch. (2019, September 30). Menuju keadilan sosial dan ekologis bagi masyarakat adat/lokal, buruh dan petani [Paper presentation]. Seminar Tata Kelola Perkebunan Sawit. Jakarta.

Shohibuddin, M. (2013). Pembentukan kebijakan reforma agraria, 2006-2007. In M. Shohibuddin \& M. N. Salim (Eds.), Pembentukan kebijakan reforma agraria, 2006-2007: Bunga rampai perdebatan. Yogyakarta: STPN dan Sajogyo Institute.

Sahide, M. A. K., Fisher, M. R., Maryudi, A., Wong, G. Y., Supratman, \& Alam, S. (2019). The bureaucratic politics of conservation in governing land conflict: A typology of capacities. MethodsX, 6, 2536-2543. https://doi.org/ 10.1016/j.mex.2019.10.022

Tjondronegoro, S. M. P. (1982). Peranan beberapa lembaga dalam hubungan reforma agraria. In Land reform $d i$ Indonesia. Jakarta: Direktorat Agraria, Departemen Dalam Negeri.

Widodo, S. (2017). A critical review of Indonesia's agrarian reform policy. Journal of Regional and City Planning, 28(3), 204-218.

Wiradi, G. (2005). Reforma agraria: Untuk pemula. Jakarta: Sekretariat Bina Desa.

Winoto, J. (2010). Tanah untuk keadilan dan kesejahteraan rakyat. Jakarta: Badan Pertanahan Nasional Republik Indonesia.

Wurfel, D. (1988). Filipino politics: Development and decay. Ithaca: Cornell University Press. 